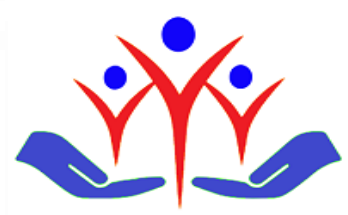

Research Article

\title{
Self-efficacy, medical adherence and related factors in patients with diabetes
}

\author{
Diyabetli hastalarda öz-etkililik, tedaviye uyum ve ilişkili faktörler
}

\author{
(D) Didem Sahina, (iD Suleyman Ersoy ${ }^{\mathbf{a}}$, Emin Pala ${ }^{\mathbf{a}}$ \\ a Department of Family Medicine, Umraniye Training and Research Hospital, University of Health Sciences, Istanbul, Turkey
}

\begin{abstract}
Introduction: The aim of the current study was to determine the self-efficacy and the medical adherence levels of the patients with type 2 diabetes and related factors in primary care.

Methods: This was a descriptive study which was conducted in a family health center in Istanbul between February 2020 and May 2020. Information was collected from the patients over the age of 18 with a diagnosis of type 2 diabetes. A sociodemographic questionnaire form, SelfEfficacy Scale and Morisky Medication Adherence Scale were applied to participants face-to-face.

Results: Two hundred and seven patients were included. Mean age of the participants was $59.05 \pm 10.74$ years. Sixty percent of them were women, $85.0 \%$ were over 50 years, $69.9 \%$ had an additional disease, about half of them were diagnosed with diabetes for 10 years or more. It was found that individuals with diabetes had a median self-efficacy score of 72(64-79). The self-efficacy scores were higher in patients with normal BMI, those without additional disease and those with high physical activity level ( $\mathrm{p}=0.004, \mathrm{p}=0.038, \mathrm{p}=0.002$ respectively). The medication adherence level was found medium in 174 (84.1\%) of the patients. As the age increased medication adherence also tended to increase, and the adherence of people with normal BMI was higher ( $\mathrm{p}=0.019$ and $\mathrm{p}=0.026$ respectively).

Conclusion: The self-efficacy and medical adherence of the diabetic patients participated in the current study were found to be at medium levels. It is understood that steps are needed to improve patients' self-efficacy levels and to increase their compliance with treatment.
\end{abstract}

Keywords: Type 2 diabetes, self-efficacy, medication adherence, primary care

\section{$\ddot{O ̈ z}$}

Giriş: Bu çalışmanın amacı birinci basamakta tip 2 DM tanılı kişilerin öz-etkililik düzeyini ve ilaç tedavisine bağlılı̆̆ını ve ilişkili faktörleri belirlemektir.

Yöntem: Tanımlayıcı tipteki çalışmamız İstanbul ilinde bir aile sağlı̆̆ı merkezinde Şubat ve Mart 2020 tarihleri arasında yürütülmüştür. On sekiz yaş üstü tip 2 diyabet tanılı hastalardan bilgi toplanmıştır. Sosyodemografik özellikli bir anket, Öz-etkililik Ölçeği ve Morisky Tedavi Uyum Ölçeği katılımcılara yüz yüze uygulanmıştır.

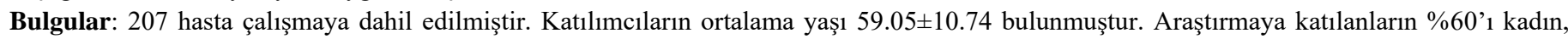
\%85,0'i 50 yaş üstü, \%69,9'u ek hastalık sahibi ve yaklaşık yarısı 10 yıl ve üzeri diyabet tanılıdır. Çalışmamız sonuçlarına göre diyabetli bireylerin öz-etkililik ortanca skoru 72(64-79 bulunmuştur. Normal BKI sahip kişilerin, ek hastalığı olmayanların ve fiziksel aktiflik düzeyi yüksek olanların öz-etkililik puanlarının daha yüksek olduğu görülmüştür (sırasıyla p=0.004, p=0.038, p=0.002) Araştırmamızda 174 (\% 84.1) hastanın ilaç uyumu orta düzeyde bulunmuştur. Yaş artıkça ilaç uyumu oranının artma eğilimi tespit edilmiş ve normal vücut kitle indeksine sahip kişilerin tedavi uyumu daha yüksek bulunmuştur (sırasılyla $\mathrm{p}=0.019$ ve $\mathrm{p}=0.026$ ).

Sonuç: Çalışmamıza katılan diyabetli hastaların öz-etkililik skorları ve tedaviye uyumlarının orta seviyelerde olduğu gözlenmiştir. Hastaların öz etkililik düzeylerinin geliştirilmesine ve tedaviye uyumunun arttırılmasına yönelik adımlara ihtiyaç duyulduğu anlaşılmaktadır.

Anahtar kelimeler: Tip 2 diyabet, öz-etkililik, ilaç uyumu, birinci basamak

\begin{tabular}{|c|c|c|c|c|}
\hline Received & Accepted & Published Online & Corresponding Author & E-mail \\
\hline October 13, 2020 & February 11, 2021 & April 3, 2021 & Suleyman Ersoy, MD & suleymanersoy@gmail.com \\
\hline Correspondence & $\begin{array}{l}\text { Suleyman Ersoy, Ümraniye Ĕ̆itim ve Araştırma Hastanesi, Aile Hekimliği Kliniği, Adem Yavuz } \\
\text { Caddesi, No:1 Ümraniye, İstanbul, Turkey }\end{array}$ \\
\hline
\end{tabular}




\section{Introduction}

Diabetes Mellitus (DM) is a chronic, metabolism disorder with a wide spectrum requiring continuous medical care where organism cannot benefit from carbohydrates, lipids and proteins of the body due to insulin insufficiency or defective insulin effects [1]. Currently, diabetes is encountered as an ever-increasing health issue worldwide due to its high prevalence and problems created as a result of it. Rapid change in life style of the people in developed or developing countries has led to a great increase in prevalence of type 2 diabetes in all of these populations. As of 2013 the number of diabetic patients is 382 million worldwide; however this number is estimated to reach 592 million by $55 \%$ increase in 2035 [2]. In Turkey TURDEP-II trial has assessed 26.499 people over 20 years old country-wide and has shown that prevalence of type 2 diabetes increased in recent years significantly and reached to $13.7 \%$ [3].Therefore establishing national measures in order to cope with diabetes and its unwanted consequences is of paramount importance.

Social Cognitive Theory provides a useful frame for understanding how behaviors and activities act together [4]. According to Bandura, perceived self-efficacy (SE) is evaluation of ability of one to exhibit an effective and complete performance in a certain situation. For personal well-being strong self-efficacy feeling is required and it helps maintaining efforts toward success. Therefore, SE decisions have a role in determining which activities and situations a certain person will perform or not [5].

Systemic reviews have revealed that improving DM patients' self-efficacy will accordingly improve their self-management ability. For patients having health problems requiring complex management and care such as diabetes expectations regarding outcomes and self-efficacy belief play important role to take necessary steps toward life style changes and to learn new skills in order to cope with disease process. Diabetes management encompasses not just compliance to the treatment but also some behavior changes in daily practice of the patient. "Self-efficacy" concept is pointed out as the key to carry out required behavior changes and to reach at desired goals. For coping with complex care and treatment effectively adequate self-efficacy is a desired attribute in diabetic patients $[6,7]$.

Furthermore, in long-term treatment of chronic diseases like DM, lack of medication adherence is one of the most common reasons of patients not getting enough benefit from the drugs. Inadequate medication adherence contributes to increases in morbidity, mortality, and health care costs, as well as frustration among patients and providers. Improving medication adherence may have a greater influence on the health of our population than in the discovery of any new therapy. Patients are nonadherent to their medicine 50\% of the time. Although most physicians believe nonadherence is primarily due to lack of access or forgetfulness, nonadherence can often be an intentional choice made by the patient. A systematic review of the literature about medical adherence with diabetes has concluded that higher adherence was associated with improved glycemic control, fewer emergency department visits, decreased hospitalizations, and lower medical costs in DM patients [8-10].

Self-efficacy and medication adherence level in management of the disease and determining their relationship emerge as an important parameter in patients with DM $[9,11]$. The aim of our study is to determine the self-efficacy and the medical adherence level of the patients with type 2 diabetes who referred to a primary care unit. Besides we aimed to evaluate the relationship of these levels with each other and with sociodemographic characteristics, disease / health characteristics and clinical indicators.

\section{Methods \\ Study design}

Our study is a cross-sectional descriptive study. The study was conducted in province of Istanbul at Umraniye county 6th Family Health Center (FHC). Population registered to the FHC was about 3500. When incidence rate of the condition was assumed to be 15\%, design effect 1, error rate $5 \%$ and confidence interval 95\%, sample size to be reached was estimated as 196 (3). All consecutive DM patients who fulfilled the inclusion criteria and who have referred to 6th Family Health Center between February 2020 and May 2020 (rather than random sampling from the population) were included in the study. Inclusion criteria for the study; diabetes diagnosis established by a doctor, being literate, no language barrier or speaking-hearing disability, adequate cognitive capacity, 18 years or older and consent for participation to the study.

Exclusion criteria for the study; recently diagnosed severe psychiatric disorders such as psychosis, dementia, major depression, visual or hearing disability, mental deficiency and being younger than 18 years old.

\section{Data collection and content of the questionnaire}

The questionnaire which included sociodemographic information and information about the chronic diseases of the patients was designed by consulting the Public Health Department of Health Sciences University. Type 2 Diabetes Mellitus Self-Efficacy Scale, Morisky Medication Adherence Scale (MMAS) and the questionnaire were conducted with face-to-face interviews. Additionally, latest laboratory values provided from database, data regarding health behavior of the patients, body mass indexes (BMI) and clinical indicators (HbA1c) were also recorded. BMI is calculated as $\mathrm{BMI}=\mathrm{kg} / \mathrm{m}^{2}$

\section{Variables}

Dependent variables of the study were self-efficacy scores of Type 2 DM patients and their medical adherence levels whereas the independent variables were sociodemographic characteristics (age, sex, education level, employment status, comorbidities, alcohol/smoking habits, physical activity) diabetes education, presence of self-monitoring of blood glucose (SMBG) and HbA1c level as clinical indicator (HbA1c levels were obtained from the database of the family medicine software program retrospectively. The data within the last one year was included in the study). 


\section{Type 2 DM self-efficacy scale}

Type 2 DM self-efficacy scale is developed by Van der Bijl et al [12]. This tool is very important since it provides standard data that may be used in clinical practice and clinical studies. Original Type 2 DM self-efficacy scale comprises from 5 point Likert response format using a 20 item summary grading scale used for measuring power dimension of SE regarding diabetes management tasks required to control DM including exercise, monitoring of blood glucose, adherence to recommended diet. Validation study has shown presence of internal consistency $(\alpha=0.81$ coefficient) and r=0.79 test-retest reliability. Factor analysis has defined four factors related with self-management activities: weight control, overall diet related with medical treatment, physical exercise and adequate diet related with metabolic control. $\alpha$ co-efficient of these 4 factors changes between 0.71 and 0.79 , all of them explain $55 \%$ of the variance. This is consistent with SE theory, because adherence to certain behaviors enables a person to manage his/her health problems. Turkish validation and reliability study was carried out by Kara et al. [13]. Scale items were graded by Likert type of scoring changing from 1 to 5 ( $5=$ Yes, I am sure), $4=$ Yes, $3=$ Neither yes nor no), 2=No, $1=$ No, I am not sure). In intercultural adaptation study carried out by Kara et al, three dimensions of the scale was reported. These dimensions are diet + foot control, medical treatment and physical exercise [12,13]. Cronbach's alpha value was found as 0.89 for the whole scale. It was observed that scale has a 3 -factor structure. In reliability study, internal consistency of self-efficacy scale was 0.88 and correlation between items was 0.91 ; thus it was observed that self-efficacy scale is valid and reliable for Turkish. The lowest possible score is 20 and the highest possible score is 100 for the scale.

\section{Morisky Medication Adherence Scale}

Morisky Medication Adherence Scale (MMAS) developed by Morisky et. al. as a 4-item scale to assess medication adherence in primary care will be used in this study; validation and reliability of this scale in Turkish was assessed by Bahar et al. [14]. İnternal consistency coefficient was 0.62 , test-re-test reliability co-efficient was between 0.64-0.96. Scale is a self-assessment tool filled by the patient to measure medication adherence. Questions are 'yes or no' questions. If all of the responses is 'no', then medication adherence is high, if 1 or 2 response is 'yes' adherence is 'medium', if 3 or 4 response is yes' adherence is low. In factor analysis KMO value was 0.636 ; Bartlett's test result was 29.312 and it was determined that items are correlated with each other. It was determined that most of the variables are co-variates and concentrate on one factor and total variance rate of the scale is an adequate value. Response of patient relatives and blood drug levels were considered as external consistency measure, statistically significant concordance between these measures and MMAS results was determined.

\section{Statistical analysis}

All statistical analysis was carried out using the Statistical Package for the Social Sciences software, version 25.0 (IBM SPSS, Chicago, IL, USA). Obtained data is reported as descriptive statistics (frequencies, median (IQR), percentage distribution). Conformity to normal distribution was assessed by Kolmogorov Smirnov and Shapiro Wilk tests before making comparison between variables. Continuous variables which distributed normally were expressed as mean \pm standard deviation whereas abnormally distributed variables as median(inter quantile range-IQR). For comparison of average of two independent groups, if parametric conditions aren't met then Mann Whitney U test was used. For comparison of average of more than two independent groups, if parametric conditions aren't met then Kruskal Wallis Variance Analysis was used. For percentage distribution of categorical data between groups Chi-square test was used and $\mathrm{P}<0.05$ was considered significant.

\section{Ethical approval}

The study protocol was approved by Clinical Studies Ethics Committee of Health Sciences University Umraniye Training and Research Hospital (date February 19, 2020 Decision no:32). Written informed consent of the participants were taken prior to the study.

\section{Results}

A total of 207 patients were included in our study and 59.9\% of them were female $(n=124)$ while $40.1 \%$ were male ( $n=83)$. Mean age of the patients was $59.05 \pm 10.74$ years. The majority of patients were in 60-70 years old group. Almost half of the participants (49.3\%) were primary school graduates. A substantial amount of the patients were retired (39.6\%). 45.0\% of the participants were obese and $40.6 \%$ overweight while $69.9 \%$ of the patients had co-morbid disease. Alcohol use was $3.9 \%$ and $16.5 \%$ was smoker. $36.6 \%$ were doing moderate physical activity at least 3 days of the week, at least half an hour. Monitoring of blood glucose was carried out by $72.3 \%$ of the participants and $26.5 \%$ of the participants were using insulin. Almost half of the patients (46.8\%) were diagnosed as having DM for 10 years or more (Table 1).

Within the last one year in $81.2 \%(\mathrm{n}=168)$ of the patients data regarding HbA1c value could be obtained. In 70.2\% ( $\mathrm{n}=118)$ of those patients $\mathrm{HbA} 1 \mathrm{c}$ was found to be $6.5 \%$ or more. Medication adherence was medium in majority of the patients (\%84.1, n=174) and median of DM selfefficacy score was 72(64-79) (Table 2). 
Table 1. Sociodemographic and Health Characteristics of the Participants

\begin{tabular}{|c|c|c|c|}
\hline \multicolumn{2}{|r|}{ Sociodemographic and Health Characteristics } & \multirow{2}{*}{$\begin{array}{c}\text { No }(\mathbf{n}) \\
31\end{array}$} & \multirow{2}{*}{$\begin{array}{c}\text { Percentage }(\%) \\
15.0\end{array}$} \\
\hline \multirow{4}{*}{ Age } & $<50$ years old & & \\
\hline & 50 to 60 years old & 71 & 34.3 \\
\hline & 60 to 70 years old & 74 & 35.7 \\
\hline & $>70$ years old & 31 & 15.0 \\
\hline \multirow{2}{*}{ Sex } & Female & 124 & 59.9 \\
\hline & Male & 83 & 40.1 \\
\hline \multirow{5}{*}{ Education } & Literate & 18 & 8.7 \\
\hline & Primary school & 102 & 49.3 \\
\hline & Middle-school & 29 & 14 \\
\hline & High school & 34 & 16.4 \\
\hline & University or above & 24 & 11.6 \\
\hline \multirow{5}{*}{ Income level } & No regular income & 22 & 10.7 \\
\hline & Up to $2500 \mathrm{TL}$ & 76 & 37.1 \\
\hline & $2500-5000 \mathrm{TL}$ & 69 & 33.7 \\
\hline & $5000-7500 \mathrm{TL}$ & 21 & 10.2 \\
\hline & More than $7500 \mathrm{TL}$ & 17 & 8.3 \\
\hline \multirow{8}{*}{ Occupation } & Employee (including public work) & 16 & 7.7 \\
\hline & Self-employee of family business & 17 & 8.2 \\
\hline & Casual worker & 1 & 0.5 \\
\hline & Seeking job or jobless & 5 & 2.4 \\
\hline & Inability to work due to disease or disabled & 6 & 2.9 \\
\hline & Retired & 82 & 39.6 \\
\hline & House work & 68 & 32.8 \\
\hline & Other & 12 & 5.8 \\
\hline \multirow{4}{*}{ BMI } & Lean & 1 & 0.5 \\
\hline & Normal & 28 & 13.9 \\
\hline & Overweight & 82 & 40.6 \\
\hline & Obese & 91 & 45.0 \\
\hline \multirow{2}{*}{$\begin{array}{l}\text { Co-morbid } \\
\text { disease }\end{array}$} & Yes & 62 & 30.1 \\
\hline & No & 144 & 69.9 \\
\hline \multirow{3}{*}{ Smoking habit } & No. never & 113 & 54.9 \\
\hline & I quit & 59 & 28.6 \\
\hline & Yes. I have & 34 & 16.5 \\
\hline \multicolumn{2}{|c|}{ Sociodemographic and Health Characteristics } & No (n) & Percentage $(\%)$ \\
\hline \multirow{2}{*}{ Alcohol use } & No & 199 & 96.1 \\
\hline & Yes & 8 & 3.9 \\
\hline \multirow{4}{*}{$\begin{array}{l}\text { Physical activity } \\
\text { level }\end{array}$} & No & 72 & 35.1 \\
\hline & Occasionally & 75 & 36.6 \\
\hline & At least 3 times a week. at least half an hour. mid-level & 54 & 26.3 \\
\hline & At least 3 times a week. at least half an hour. intense & 4 & 2.0 \\
\hline \multirow{2}{*}{ SMBG present } & Yes & 149 & 72.3 \\
\hline & No & 57 & 27.7 \\
\hline \multirow{3}{*}{ DM duration } & Up to 5 years & 55 & 27.4 \\
\hline & 5 to 10 years & 52 & 25.9 \\
\hline & $>10$ years & 94 & 46.8 \\
\hline \multirow{2}{*}{ DM education } & No & 157 & 77.0 \\
\hline & Yes & 47 & 23.0 \\
\hline \multirow{2}{*}{ Insulin } & Yes & 54 & 26.5 \\
\hline & No & 150 & 73.5 \\
\hline
\end{tabular}

BMI; body mass index, SMBG; self-monitoring blood glucose, DM; diabetes mellitus

Table 2. Medication adherence and self-efficacy of participants

\begin{tabular}{|c|c|c|c|c|}
\hline & & & No $(\mathbf{n})$ & Percentage (\%) \\
\hline \multirow{3}{*}{$\mathrm{HbA1c}$} & $<6.5 \%$ & & 50 & 29.8 \\
\hline & $6.5 \% \leq$ & & 118 & 70.2 \\
\hline & Low & & 32 & 15.5 \\
\hline \multirow{3}{*}{ Level of medication adherence } & Medium & & 174 & 84.1 \\
\hline & High & & 1 & 0.5 \\
\hline & & DM self-efficacy & $72 *$ & $64-79 * *$ \\
\hline
\end{tabular}

*Median **IQR (Inter quantile range; 25 . percentile -75 . Percentile)

Regarding the self-efficacy scores of the participants, it was found that patients without a co-morbid disease had a self-efficacy median score of 76(66-80) while it was 71(63-78) in those with co-morbid diseases ( $\mathrm{p}=0.038)$. Moreover, in patients reporting physical activity as "none" selfefficacy median score was 68(58-76) and as physical activity increased median score has increased respectively to 74 (63-80), 75(66-79) and 88(77-97). It was observed that there was a trend towards an increase in self-efficacy score as physical activity frequency and intensity increased 
$(\mathrm{p}=0.002)$. Dual comparisons revealed that patients who reported a physical activity of at least 3 times a week, at least half an hour, intense $(88(77-$ 97)) had higher self-efficacy scores than who reported physical activities of mid-level (75(66-79)), occasionally (74(63-80)) and none (68(58-76)) $(\mathrm{p}=0.030, \mathrm{p}=0.010, \mathrm{p}=0.001$ respectively). Comparing self-efficacy of participants according to age $(\mathrm{p}=0.906)$, sex $(\mathrm{p}=0.925)$ and education status revealed no statistically significant relationship. However, in obese patients' self-efficacy median score was 69 and in overweight patients 75 and in normal or lean patients 76 and it was observed that as self-efficacy score increased BMI decreased to normal levels ( $\mathrm{p}=0.004)$. Dual comparisons revealed that obese patients had lower scores when compared to overweight and normal/underweight patients ( $\mathrm{p}=0.003 \mathrm{and} \mathrm{p}=0.001 \mathrm{respectively)}$. Analysis carried out according to health status of the patients has revealed no statistically significant relationship between self-efficacy scores and DM duration $(\mathrm{p}=0.388)$, Hbalc value $(\mathrm{p}=0.639)$ and medication adherence level $(\mathrm{p}=0.833)$ (Table 3$)$.

Table 3. Self-efficacy scores according to sociodemographic and health characteristics

\begin{tabular}{|c|c|c|c|c|c|}
\hline \multicolumn{2}{|r|}{ Sociodemographic and health characteristics } & \multicolumn{3}{|c|}{ Self-efficacy scores } & \multirow{2}{*}{ P value } \\
\hline & 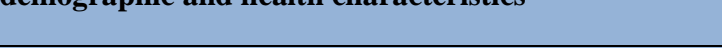 & Median & 25.p & 75.p & \\
\hline \multirow{4}{*}{ Age } & $>50$ years old & 73 & 64 & 79 & \multirow{4}{*}{$0.906^{* *}$} \\
\hline & 50 to 60 years old & 75 & 64 & 80 & \\
\hline & 60 to 70 years old & 72 & 64 & 78 & \\
\hline & $>70$ years old & 70 & 60 & 79 & \\
\hline \multirow{2}{*}{ Sex } & Female & 73 & 64 & 80 & \multirow{2}{*}{$0.925 *$} \\
\hline & Male & 70 & 64 & 79 & \\
\hline \multirow{3}{*}{ Education } & Under high school & 72 & 64 & 80 & \multirow{2}{*}{$0.807 *$} \\
\hline & High school or above & 73 & 64 & 79 & \\
\hline & Up to minimum wage & 70 & 60 & 80 & \multirow{3}{*}{$0.732 * *$} \\
\hline \multirow[t]{3}{*}{ Income level } & Up to $2 X$ minimum wage & 73 & 64 & 78 & \\
\hline & More than $2 \mathrm{X}$ minimum wage & 75 & 64 & 78 & \\
\hline & Lean and Normal & 76 & 64 & 80 & \\
\hline \multirow[t]{2}{*}{ BMI } & Overweight & 75 & 66 & 80 & \multirow[t]{2}{*}{$0.004 * *$} \\
\hline & Obese & 69 & 60 & 76 & \\
\hline \multirow{3}{*}{ Co-morbid disease } & Yes & 76 & 66 & 80 & \multirow{3}{*}{$0.038 *$} \\
\hline & No & 71 & 63 & 78 & \\
\hline & No. never & 74 & 64 & 80 & \\
\hline \multirow[t]{2}{*}{ Smoking habit } & I quit & 71 & 64 & 77 & \multirow[t]{2}{*}{$0.361 * *$} \\
\hline & Yes. I have & 68 & 60 & 80 & \\
\hline \multirow{3}{*}{ Alcohol use } & No & 72 & 64 & 80 & \multirow{3}{*}{$0.598^{*}$} \\
\hline & Yes & 70 & 61 & 78 & \\
\hline & No & 68 & 58 & 76 & \\
\hline \multirow{3}{*}{$\begin{array}{l}\text { Physical activity } \\
\text { level }\end{array}$} & Occasionally & 74 & 63 & 80 & \multirow{3}{*}{$0.002 * *$} \\
\hline & At least 3 times a week. at least half an hour. mid-level & 75 & 66 & 79 & \\
\hline & At least 3 times a week. at least half an hour. intense & 88 & 77 & 97 & \\
\hline \multirow{3}{*}{ SMBG } & Yes & 73 & 64 & 80 & \multirow{3}{*}{$0.200 *$} \\
\hline & No & 71 & 57 & 78 & \\
\hline & Up to 5 years & 73 & 66 & 80 & \\
\hline \multirow[t]{2}{*}{ DM duration } & 5 to 10 years & 70 & 60 & 80 & \multirow[t]{2}{*}{$0.388 * *$} \\
\hline & $>10$ years & 73 & 64 & 79 & \\
\hline \multirow{2}{*}{ DM education } & No & 71 & 63 & 78 & \\
\hline & Yes & 75 & 66 & 80 & $0.324^{*}$ \\
\hline Insulin & Yes & 69 & 64 & 78 & \\
\hline Insulin & No & 73 & 64 & 80 & $0.538^{*}$ \\
\hline & $<6.5 \%$ & 76 & 80 & 80 & $0.620 *$ \\
\hline HbAlc & $6.5 \% \leq$ & 71 & 64 & 79 & $0.639^{*}$ \\
\hline Medical adherenc $\mathrm{C}$ & Low & 70 & 63 & 80 & $0833 *$ \\
\hline Nedical adnerence & Medium and high & 73 & 64 & 79 & $0.833^{*}$ \\
\hline
\end{tabular}

* Mann Whitney U **Kruskal Wallis Variance Analysis, BMI; body mass index, SMBG; self-monitoring blood glucose, DM; diabetes mellitus

Regarding the medication adherence levels, it was found that with increasing age, medium/high adherence rate has increased as in terms of percentage ( $<50$ years old $74.2 \%$ medium/high medication adherence, $\geq 70$ years old $93.5 \%$ medium $/$ high medication adherence) $(\mathrm{p}=0.019)$. However, there was no statistically significant difference between participants according to $\operatorname{sex}(\mathrm{p}=0.947)$, education status $(\mathrm{p}=0.679)$ and income level $(\mathrm{p}=0.873$ ). Comparison regarding body mass index has shown that in lean/normal group medication adherence was medium/high with $93,1 \%$ and obese patients it was still medium/high with $78 \%$ (Trend $\mathrm{p}=0.026$ ) (Table 4). 
Table 4. Medication adherence according to sociodemographic and health characteristics

\begin{tabular}{|c|c|c|c|c|}
\hline & & Medic & rence & \\
\hline Socio & emographic and health characteristics & Low n $(\%)$ & $\begin{array}{c}\text { Medium/High n } \\
(\%)\end{array}$ & $P$ value \\
\hline & $>50$ years old & $8(25.8)$ & $23(74.2)$ & \\
\hline 1 & 50 to 60 years old & $13(18.3)$ & $58(81.7)$ & \\
\hline nge & 60 to 70 years old & $9(12.2)$ & $65(87.8)$ & $0.019 \mathrm{x}$ \\
\hline & $>70$ years old & $2(6.5)$ & $29(93.5)$ & \\
\hline $\mathrm{C}=\mathrm{O}$ & Female & $19(15.3)$ & $105(84.7)$ & \\
\hline $\mathrm{SeX}$ & Male & $13(15.7)$ & $70(84.3)$ & $0.94 /$ \\
\hline & Under high school & $24(16.1)$ & $125(83.9)$ & \\
\hline Luteation & High school or above & $8(13.8)$ & $50(86.2)$ & 0.073 \\
\hline & Up to minimum wage & $16(16.3)$ & $82(83.7)$ & \\
\hline Income level & Up to $2 \mathrm{X}$ minimum wage & $10(14.5)$ & $59(85.5)$ & $0.873 *$ \\
\hline & More than $2 \mathrm{X}$ minimum wage & $6(15.8)$ & $32(84.2)$ & \\
\hline & Lean and Normal & $2(6.9)$ & $27(93.1)$ & \\
\hline BMI & Overweight & $10(12.2)$ & $72(87.8)$ & $0.026 *$ \\
\hline & Obese & $20(22.0)$ & $71(78.0)$ & \\
\hline Co-morbid & Yes & $11(17.7)$ & $51(82.3)$ & 0566 \\
\hline disease & No & $21(14.6)$ & $123(85.4)$ & 0.500 \\
\hline & No. never & $17(15.0)$ & $96(85.0)$ & \\
\hline Smoking habit & I quit & $11(18.6)$ & $48(81.4)$ & 0.662 \\
\hline & Yes. I have & $4(11.8)$ & $30(88.2)$ & \\
\hline A 1 & No & $32(16.1)$ & 167 (83.9) & 0 G10* \\
\hline A & Yes & $0(0.0)$ & $8(100)$ & $0.012 \%$ \\
\hline & No/Occasionally & $26(17.7)$ & $121(82.3)$ & \\
\hline $\begin{array}{l}\text { Physical } \\
\text { activity level }\end{array}$ & $\begin{array}{l}\text { At least } 3 \text { times a week. at least half an hour. } \\
\text { mid-level/intense }\end{array}$ & $5(8.6)$ & 53 (91.4) & 0.103 \\
\hline Blood glucose & Yes & $23(15.4)$ & $126(84.6)$ & 005 \\
\hline monitoring & No & $9(15.8)$ & $48(84.2)$ & \\
\hline & Up to 5 years & $10(18.2)$ & $48(81.8)$ & \\
\hline DM duration & 5 to 10 years & $11(21.2)$ & $41(78.8)$ & 0.283 \\
\hline & $>10$ years & $11(11.7)$ & $83(88.3)$ & \\
\hline DM & No & $24(15.3)$ & $133(84.7)$ & 000 \\
\hline 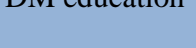 & Yes & 7 (14.9) & $40(85.1)$ & 0.940 \\
\hline & Yes & $10(18.5)$ & $44(81.5)$ & \\
\hline msumm & No & $22(14.7)$ & $128(85.3)$ & $0.50 J$ \\
\hline & $<\% 6.5$ & $9(18.0)$ & $41(82.0)$ & 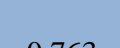 \\
\hline ПОАІС & $\% 6.5 \leq$ & $19(16.1)$ & 99 (83.9) & 0.105 \\
\hline
\end{tabular}

*Trend chi-square ** Fisher exact Test

\section{Discussion}

In our study conducted in adult diabetic patients referring to a primary care unit; participants often have medium level self-efficacy; however selfefficacy of patients having normal body mass index, not having co-morbid disease and those physically more active tend to be higher. Medication adherence was found to be low-medium but adherence increased by increasing age.

In the scale showing self-efficacy, median score was 72 in diabetic patients participating in the study. When the lowest and highest possible scores of the scale is considered, score average obtained in the end of the study was at medium level scores. There are studies reporting similar results to ours. Among them, a study by Kav et al. investigated self-care activities, depression and self-efficacy in Turkish diabetic patients and mean selfefficacy score was found 66 [15]. In the study of Erol et al. self-efficacy scale total score average was 68 [16]. In the study carried out by Akpunar 
et al. assessing impact of diabetes education on diabetes management, before the intervention self-efficacy scale total score average was 68 in the intervention group and 69 in control group; after the intervention total scale score average was 76 in the intervention group and 70 in the control group [17]. It was found as 65 in the study conducted by Gedik et. al. [18]. In the study by Kilic et al. association of self-efficacy level with health locus of control was investigated and total scale score average was found as 71 [19]. However, in the study of Arpaci Eren et al. investigating impact of diabetes school on self-efficacy perception of the diabetic patients, initial score average was 45 in the experimental group and 46 in the control group; after 3 months of education the score was 57 in the experimental group and much lower, 43 in the control group [20]. Also, in the study by Ozdemir et al. self-efficacy scale total score average was found as 51 [21]. Based on the results of our study and the literature we can state that self-efficacy level of diabetic patients in our country regarding diabetes is generally low-medium. We think, required long-term management and care in diabetic patients is the main reason for low-medium self-efficacy level and necessary steps to improve self-efficacy level of these patients should be taken.

When self-efficacy scores of the patients were compared according to sociodemographic characteristics of the participants (age, sex, education status and income status) no statistically significant association was found. There are studies in the literature in concordance with our study in terms of inability to find any association with age [15, 18, 21].

By increasing age diabetic patients get adapted to living in conformity with diabetes, develop coping mechanisms and thus their self-efficacy level may be high. At the same time, it's stated that presence of different chronic diseases may negatively impact self-efficacy [22]. Although there are studies about absence of sex difference [15, 19], in other studies it's reported that in male self-efficacy level is higher [18, 21, 23]. In terms of education status, median score was higher in graduates of high school or above but it wasn't statistically significant. However, in the literature it's suggested that self-efficacy score increases along with increasing education level $[15,18,24]$. This may be related with increased knowledge and awareness of the higher educated people that may lead to sensitivity about the disease. In our study median score increased with increasing income level but the difference wasn't statistically significant. In previous studies also a clear association wasn't observed and there are conflicting results $[15,16,19,24]$.

In this study, self-efficacy score was statistically significantly higher in patients with lean and normal body mass index, having no co-morbid disease and with higher physical activity level compared to other patients. There are studies which did not reveal any significant correlation between BMI and self-efficacy [25]. There are other contrary studies indicating lower self-efficacy score in patients with normal BMI [17]. In the literature presence of co-morbid disease/complication wasn't found to be associated with self-efficacy $[15,16,18]$. It's reported in the study of Erol $\mathrm{O}$ et al. self-efficacy score of patients doing regular exercise was significantly higher [16]. The study by Akpunar et al. also has found positive correlation between regular exercise and self-efficacy score [17]. Regular exercise which is one of the mainstays of healthy life is an indicator for the perceived importance of personal health for a certain patient and his/her conformity with diabetes management. Higher self-efficacy score in patients doing regular exercise is also an evidence to support this view.

However, some health characteristics such as smoking and alcohol use, monitoring of blood glucose, DM duration, DM education, insulin use, Hbalc level and medication compliance was found to be not associated with self-efficacy. No association was found between diabetes duration and self-efficacy $[15,17,18]$. In various studies, it was observed that self-efficacy level has increased by increasing diabetes duration [16]. In our study, no significant association was found between monitoring of blood glucose and self-efficacy; however, in previous studies it was observed that self-efficacy level was higher in patients who respond positively to the question of presence or absence of regular health control [16, 19]. In line with our study, in various studies no association was found between smoking and self-efficacy $[15,17,18]$. In our study, self-efficacy score of patients getting diabetes education was somewhat higher but the difference wasn't statistically significant. In available publications, there are some studies showing no significant association between self-efficacy and having diabetes education/course; but in some studies self-efficacy was found to be higher in patients having diabetes education/course $[16,18]$. It's assumed that, in order to translate self-efficacy to behavior, instead of single episode of education long-term planning should be done for diabetes education and interviews and regular follow-up and monitoring will also be effective in increasing self-efficacy scores. Association between insulin use and self-efficacy is another area with conflicting results in the literature. There was no clear association [16-19]. In the studies usually no association was found between HbA1c level and self-efficacy [15, 18]. In the study of by Akpunar self-efficacy score of those with HbA1c 8,3\% was found to be significantly lower [17]. However, this result may stem from much higher cut-off point in above mentioned study than the cut-off point in our study $(6.5 \%)$.

In our study, medication adherence of the patients was mostly at medium level. However, adherence being lower in some patients but high only in one patient suggests some shortcomings in this area. Moreover, this result based on self-report of the patients carries a risk of bias in that the responses could have been distorted in order to give better impression about adherence and thus real adherence level could be worse than the selfreported level.

When medication adherence is assessed according to sociodemographic characteristics, except from the age there was no significant difference between any of the variables. In line with increasing age rate of medium/high level of medication adherence tend to increase. Similarly, it is reported that medication non-adherence is lower in patients more than 60 years old compared to patients younger than 60 years old [25, 26]. This finding is in concordance with other studies showing medication non-compliance is prevalent in younger patients and usually linking nonadherence in younger patients to difficulty in acceptance of new diagnosis [26], limited information about the disease, fear from adverse effects and treatment regime load [27]. It's accepted that older people with longer disease duration are more aware of the disease and importance of glycemic control in prevention of complications and also supported by their families for the management of diabetes [28]. It's also observed that medication adherence is better in patients with lean/normal BMI. Although lack of information about the number of used medications is a limiting factor, it may be assumed that patients with normal BMI usually take less medicine and thus compliance may be higher. 


\section{Limitations}

Main limitation of the study is that since being a descriptive one no causality can be established. Observed associations should be interpreted cautiously. Secondly, this study is conducted in patients referred to a primary care unit, thus, the results can't be projected to all diabetic patients. In addition, data are obtained by face-to-face interviews or self-reported questionnaires; and the reliability of the data is limited with the responses of the patients

\section{Conclusion}

The results of the study revealed that self-efficacy level of diabetic patients was medium and medication adherence was low-medium. It was also observed that self-efficacy score was higher in patients with lean and normal body mass index, having no co-morbid disease and with higher physical activity level. Similar studies in larger population are needed to emphasize the importance of self-efficacy level of diabetic patients and their adherence to medication.

Acknowledgments: We wish to thank Prof. Mustafa Ozturk for his contributions to the design of the questionnaire.

Conflict of interest: None.

Financial support: None

\begin{tabular}{|c|l|l|}
\hline \multicolumn{2}{|c|}{ Author Contributions } & \multicolumn{1}{c|}{ Author Initials } \\
\hline SCD & Study Conception and Design & DS, SE \\
\hline AD & Acquisition of Data & DS \\
\hline AID & Analysis and Interpretation of Data & DS, SE, EP \\
\hline DM & Drafting of Manuscript & DS, SE, EP \\
\hline CR & Critical Revision & DS, SE, EP \\
\hline
\end{tabular}

\section{References}

1. Busolo D, Woodgate R. Palliative care experiences of adult cancer patients from ethnocultural groups: a qualitative systematic review Temd. 2020]; Available from: http://temd.org.tr/admin/uploads/tbl_kilavuz/20200625154506-2020tbl_kilavuz86bf012d90.pdf. (Access date: June 21, 2020)

2. Aguiree F, Brown A, Cho NH, Dahlquist G, Dodd S, Dunning T, et al., IDF diabetes atlas. 2013. http://dro.deakin.edu.au/view/DU:30060687

3. Satman I, Omer B, Tutuncu Y, Kalaca S, Gedik S, Dinccag N, et al. Twelve-year trends in the prevalence and risk factors of diabetes and prediabetes in Turkish adults. Eur J Epidemiol 2013; 28:169-80. https://doi.org/10.2337/diacare.24.3.561

4. Bandura A. Social foundations of thought and action. Englewood Cliffs, NJ. 1986;1986:23-8.

5. Bandura A, Freeman W, Lightsey R. Self-efficacy: The exercise of control. Springer; 1999. https://doi.org/10.1891/0889-8391.13.2.158.

6. Norris SL, Engelgau MM, Narayan KMV. Effectiveness of self-management training in type 2 diabetes: A systematic review of randomized controlled trials. Diabetes Care. 2001; 24(3):561-87. https://doi.org/10.2337/diacare.24.3.561

7. Krichbaum K, Aarestad V, Buethe M. Exploring the Connection Between Self-Efficacy and Effective Diabetes Self-f Management. The Diabetes Educator. 2003;29(4):653-62. https://doi.org/10.1177/014572170302900411

8. Conn VS, Ruppar TM. Medication adherence outcomes of 771 intervention trials: Systematic review and meta-analysis. Prev Med. 2017; 99:269-76. https://doi.org/10.1016/j.ypmed.2017.03.008

9. Brown MT, Bussell J, Dutta S, Davis K, Strong S and Mathew S. Medication adherence: truth and consequences. The American journal of the medical sciences, 2016; 351(4): 387-99. https://doi.org/10.1016/j.amjms.2016.01.010

10. Capoccia K, Odegard PS, Letassy N. Medication adherence with diabetes medication: a systematic review of the literature. Sci Diab SelfManagement Care 2016;42(1):34-71. https://doi.org/10.1177/0145721715619038

11. Shortridge-Baggett LM. Self-efficacy: measurement and intervention in nursing. Sch Inq Nurs Pract. 2001 Fall;15(3):183-8. https://pubmed.ncbi.nlm.nih.gov/11871578

12. Bijl J, Poelgeest-Eeltink AV and Shortridge-Baggett L. The psychometric properties of the diabetes management self-efficacy scale for patients with type 2 diabetes mellitus. J Adv Nurs 1999; 30(2): 352-59. https://doi.org/10.1046/j.1365-2648.1999.01077.x

13. Kara M, Van Der Bijl JJ, Shortridge-Baggett L, Asti T, Erguney S. Cross-cultural adaptation of the diabetes management self-efficacy scale for patients with type 2 diabetes mellitus: Scale development. Int J Nurs Studies 2006; 43(5):611-21. https://doi.org/10.1016/j.ijnurstu.2005.07.008

14. Bahar G, Savas HA, Unal A, Savas E, Kaya H, Bahar A. Reliability and validity of the Morisky Medication Adherence Scale for bipolar mood disorder. Anatol J Psychiatry 2014; 15(2):141-9. http://dx.doi.org/10.5455/apd.39827

15. Kav S, Yilmaz AA, Bulut Y and Dogan N. Self-efficacy, depression and self-care activities of people with type 2 diabetes in Turkey. Collegian 2017;24(1):27-35. https://doi.org/10.1016/j.colegn.2015.09.005

16. Erol O and Yanik YT. Evaluation of self-efficacy levels of individuals with type 2 diabetes. J Anatol Nurs Health Sci. 2016; 19(3):45-9 https://doi.org/10.17049/ahsbd.22818

17. Takci MA, Yildirim G. The Effect of education given to patients with diabetes in line with health belief model on their health belief, perception of self-efficacy and decision-making level. Lokman Hekim J History Med Folk Med 2021; 11(1): 73-82. https://doi.org/10.31020/mutftd.752988 
18. Gedik S and Kocoglu D. Self-efficacy level among patients with type 2 diabetes living in rural areas. Rural Remote Health $2018 ; 18(1): 4262$. https://doi.org/10.22605/RRH4262

19. Kilic M, Arslan S. Evaluation of health locus of control of individuals with type 2 diabetes. TJFMPC 2018; 12(2): 126-35. https://doi.org/10.21763/tjfmpc.432547

20. Arpaci Eren I. [The effect of diabetes school on perception of self-efficacy in people with diabetes] (In Turkish). 2018, Hasan Kalyoncu Univ. http://openaccess.hku.edu.tr/xmlui/handle/20.500.11782/1717 (Access date: June 21, 2020)

21. Ozdemir A, Kavak F, Gultekin A. Determining the self-efficacy perceived with social support in type ii diabetes patients. Turkiye Klinikleri J Nurs Sci 2019; 11(3):21-6. https://doi.org/10.5336/nurses.2019-64774

22. Beckerle CM. and Lavin MA. Association of self-efficacy and self-care with glycemic control in diabetes. Diabetes Spectrum, 2013; 26(3):172-78. https://doi.org/10.2337/diaspect.26.3.172

23. Cherrington A, Wallston KA and Rothman RL. Exploring the relationship between diabetes self-efficacy, depressive symptoms, and glycemic control among men and women with type 2 diabetes. J Behav Med 2010; 33(1): 81-9. https://doi.org/10.1007/s10865-009-9233-4

24. Erol O and Enc N. Hypoglycemia fear and self-efficacy of Turkish patients receiving insulin therapy. Asian Nurs Res 2011; 5(4): 222-8. https://doi.org/10.1016/j.anr.2011.12.001

25. Aminde LN, Tindong M, Ngwasiri CA, Aminde JA, Njim T, Fondong AA, et al. Adherence to antidiabetic medication and factors associated with non-adherence among patients with type-2 diabetes mellitus in two regional hospitals in Cameroon. BMC Endoc Dis 2019; $19(1): 35$. https://doi.org/10.1186/s12902-019-0360-9

26. Krueger KL, Botermann SG, Schorr N, Griese-Mammen U. Laufs and Schulz M. Age-related medication adherence in patients with chronic heart failure: a systematic literature review. Int J Cardiology 2015; 184: 728-35. https://doi.org/10.1016/j.ijcard.2015.03.042

27. Van Der Wal MH, Jaarsma T, Moser DK, Veeger NJ, Van Gilst VH and Van Veldhuisen DJ. Compliance in heart failure patients: the importance of knowledge and beliefs. Eu Heart J 2006; 27(4): 434-40. https://doi.org/10.1093/eurheartj/ehi603

28. Abebaw MA, Messele M, Hailu M and Zewdu F. Adherence and associated factors towards antidiabetic medication among type II diabetic patients on follow-up at University of Gondar Hospital, Northwest Ethiopia. Advanc Nurs 2016. https://doi.org/10.1155/2016/8579157 